\title{
Risk Factors in Construction Projects during Unrest Period in Yemen
}

\author{
*Ali Mohammed Alashwal',2 and Mohammed Hatim Al-Sabahi ${ }^{3}$
}

Published online: 25 January 2019

To cite this article: Ali Mohammed Alashwal and Mohammed Hatim Al-Sabahi (2018). Risk factors in construction projects during unrest period in Yemen. Journal of Construction in Developing Countries, 23(2): 43-62. https://doi.org/10.21315/ jcdc2018.23.2.4.

To link to this article: https://doi.org/10.21315/jcdc2018.23.2.4

\begin{abstract}
Construction projects are inherently exposed to various risk and uncertainties. Numerous studies have identified risk factors in construction projects in developed and developing countries. Yemen has witnessed revolutions and wars during the past six years, which affected the construction sector among other sectors. The purpose of this paper is to determine risk factors during the unrest period in Yemen. A list of 72 risk variables was developed based on the literature review followed by a questionnaire survey to determine relevant variables and factors. The results of this study explored new components of risk variables, namely environmental, resource-related, technical, conflict, design-related, profit-related, liquidity and revolution, and change. In addition, the results indicated critical risks affecting construction projects and main strategies to respond to them. The results of this paper provide an essential step for managing risks, so project managers and other professionals can ensure good project performance. However, further study is required to investigate the effectiveness of risk response strategies proposed in this paper.
\end{abstract}

Keywords: Factor analysis, Revolution, Relative importance index (RII), Risk allocation, Risk identification, Risk response

\section{INTRODUCTION}

Construction projects in developing countries have been criticised for their poor performance (Ahadzie et al., 2008; Toor and Ogunlana, 2010). Construction projects in Yemen are no exception, where most of the government projects are suffering from excessive delay, cost overrun and bad quality. The poor performance of construction projects in Yemen is correlated with a lack of appropriate project management implementation (Al-Sabahi et al., 2014). Some studies in the area of construction management in Yemen focused on the influence of project management on project performance (Al-Sabahi et al., 2014), sustainability of the construction industry (Sultan, 2005), barriers of construction development and construction cost (Sultan and Kajewski, 2004) and construction cost of housing projects (Alaghbari et al., 2011). However, there is a lack of studies about risk factors and management in construction projects in Yemen.

In general, the study of risk management in construction projects has gained attention during the past two decades. In order to achieve the objectives of construction projects and complete them successfully, extra attention must

\footnotetext{
'Department of Quantity Surveying, Faculty of the Built Environment, University of Malaya, Kuala Lumpur, MALAYSIA

${ }^{2}$ School of Engineering, Computing and Mathematics, Western Sydney University, Kingswood, AUSTRALIA ${ }^{3}$ Department of Architecture, Faculty of Engineering, Sana'a University, Sana'a, YEMEN

"Corresponding author: a.al-ashwal@westernsyndey.edu.au
} 
be paid to the identification, mitigation and monitoring various risks that may encounter during projects execution (Bing et al., 2005; Smith et al., 2009; Yuan et al., 2009). Risks become more apparent in construction projects, where there is lack of fast decisions, improper project planning and control and ineffectiveness and inefficiency during construction stage (Abednego and Ogunlana, 2006).

Proper risk management contributes to positive project performance through the conduct of different processes (Edwards and Bowen, 1998). Risk identification is one of the initial processes in risk management model (Project Management Institute [PMI], 2013), in which practitioners can determine different types of expected risks in their projects. Following risk identification, other processes can be performed during project planning and execution including risk analysis (qualitative and quantitative), risk response and risk control. This paper focuses on risk identification as a primary step in risk management.

The purpose of this paper is to identify significant risk variables in construction projects in Yemen during the political unrest period. This study attempts to perceive construction professionals' opinions about negative risks affecting their projects. Following this introduction, next section provides an overview of risk management in construction projects, risk allocation and risk response. Afterwards, we will present the development of risk taxonomy based on literature review. There will also be a discussion on the methodology of the study and procedure of data analysis which continued with the presentation of the results and discussion before we conclude the study.

\section{RISKS MANAGEMENT IN CONSTRUCTION PROJECTS}

Uncertainty in construction projects is high due to internal and external factors such as project complexity, scope change and influence of environment and economy. Risk is defined as an uncertain event or condition, which may have a positive or negative effect of project objectives including scope, schedule, cost and quality (PMI, 2013). Occasionally, risk is defined by its source. For example, risk source includes defective design, unclear contract and lack of knowledge, which can escalate to risks (Chapman and Cooper, 1983). The significance of risk can be calculated mathematically by multiplying probability of risk occurring by its impact on project objectives (Boykin et al., 1984).

Risk management is a systematic approach to dealing with risk (Edwards and Bowen, 1998). Edwards and Bowen (1998) indicated the components of risk management system, which include establish an appropriate context, set goals and objectives of risk management, identify and analyse risks, influence risk decision-making and monitor and review risk response. Based on this system and other systems, the main processes of risk management are:

1. risk management experience: defined as an adequate understanding of the rationale and formal processes of project decision-making under risk and uncertainty. This process can be measured through the availability of risk analyst such as health and safety specialist (Jannadi and Almishari, 2003),

2. risk identification and ranking: such as risk checklists,

3. risk analysis techniques: statistical techniques such as Monte Carlo simulation, which is not commonly practiced in the construction industry (Bing et al., 2005), 
4. risk responses: such as contingencies fund added to cost baseline and

5. communication or "soft systems": includes effect of experiences on risk attitudes and the interpersonal communication of risk. It is important to move towards a co-operative shared information approach to manage risk effectively (Edwards and Bowen (1998).

Risk response includes developing a strategy to dealing with the identified and quantified risk (Zhang and Fan, 2014). Risk response methods can be divided into main strategies and sub-strategies. The strategies to response to negative risks are avoid, transfer, mitigate and accept (PMI, 2013). Sub-strategies include, for example, contingency risk allocation using more accurate estimation methods (Jung et al., 2016). Regardless whether risk analysis methods (specific approach) or risk response planning methods (how to decide to response to risk) are used, risk responses must be appropriate, cost effective and applicable to the project (Fang et al., 2013).

Risk allocation includes sharing, distribution or transferring risk to a party best able manage it at least cost (Hwang et al., 2016; Zhang et al., 2016). Risk allocation depends on client's decision at the early stage of the project and project specific requirements. In addition, risk allocation depends on the contract, procurement method used in construction, risk attitude and risk management maturity of the organisation (Hwang et al., 2016). However, a risk management system is needed to ensure fair risk allocation with acceptable contract price (El-Sayegh, 2008). Although some parties can participate in risk management such as designer, subcontractor, insurer and guarantor, the contractor and client are the main parties responsible of managing the allocated risks (El-Sayegh, 2008; Smith et al., 2006). Therefore, risk is allocated to two parties: the contractor and the client. For example, technical risks such as non-completion, cost overrun and ground condition as well as risks associated with labor, materials, technology and management lie with the contractor's responsibility (Smith et al., 2006).

\section{RISK CLASSIFICATION}

The purpose of this section is to determine different risk variables that may occur in construction projects. Previous studies discuss different risk factors, which can be classified in risk taxonomy. Chapman and Ward (1994) identified two types of risks by the degree that contractor and client are willing to bear risk, namely controllable and uncontrollable risks. Options for the contractor to control risks include using different equipment, development of contingency plan, insurance and so on. The client also can control risk through different options such as less technology, more upfront design and prototype testing. The contract (i.e., agreement) between the client and contractor can be affected by the ability of each party to bear risk. While for uncontrollable risk, an agreement that ensure appropriate risk sharing is recommended (Chapman and Ward, 1994). Edwards and Bowen (1998) presented a classification of risks which falls under two main categories: natural risk and human risk. Natural risks involve weather and geological systems risks and human risk includes economic and financial, social, political, legal, health, managerial, technical and cultural risks. Each of these types consists of several risk variables. For instance, economic and financial risks include the following risk 
variables: inflation, material and labour supply, equipment availability, exchange rate, fiscal policies, interest rate, credit rating, capital supply, cash flow, rental and bankruptcy. El-Sayegh (2008) classified risks in construction into internal (related to the company or project) and external (related to market or third parties). Similarly, Zayed et al. (2008) classified risks into macro level and micro level. The first includes risks such as financial, political, market risks, while the second includes risks mainly related to the project such as contract, design, resources and quality. Bing et al. (1999) investigated risks associated with international construction joint ventures and classified risk variables into three main categories: internal, project specific and external risks. Other classifications considered the following types: financial, contractual, market/industry, project, construction site-related, company, social, political, economic, legal, environmental and development in IT and technology (Akintoye and MacLeod, 1997; De Lemos et al., 2004).

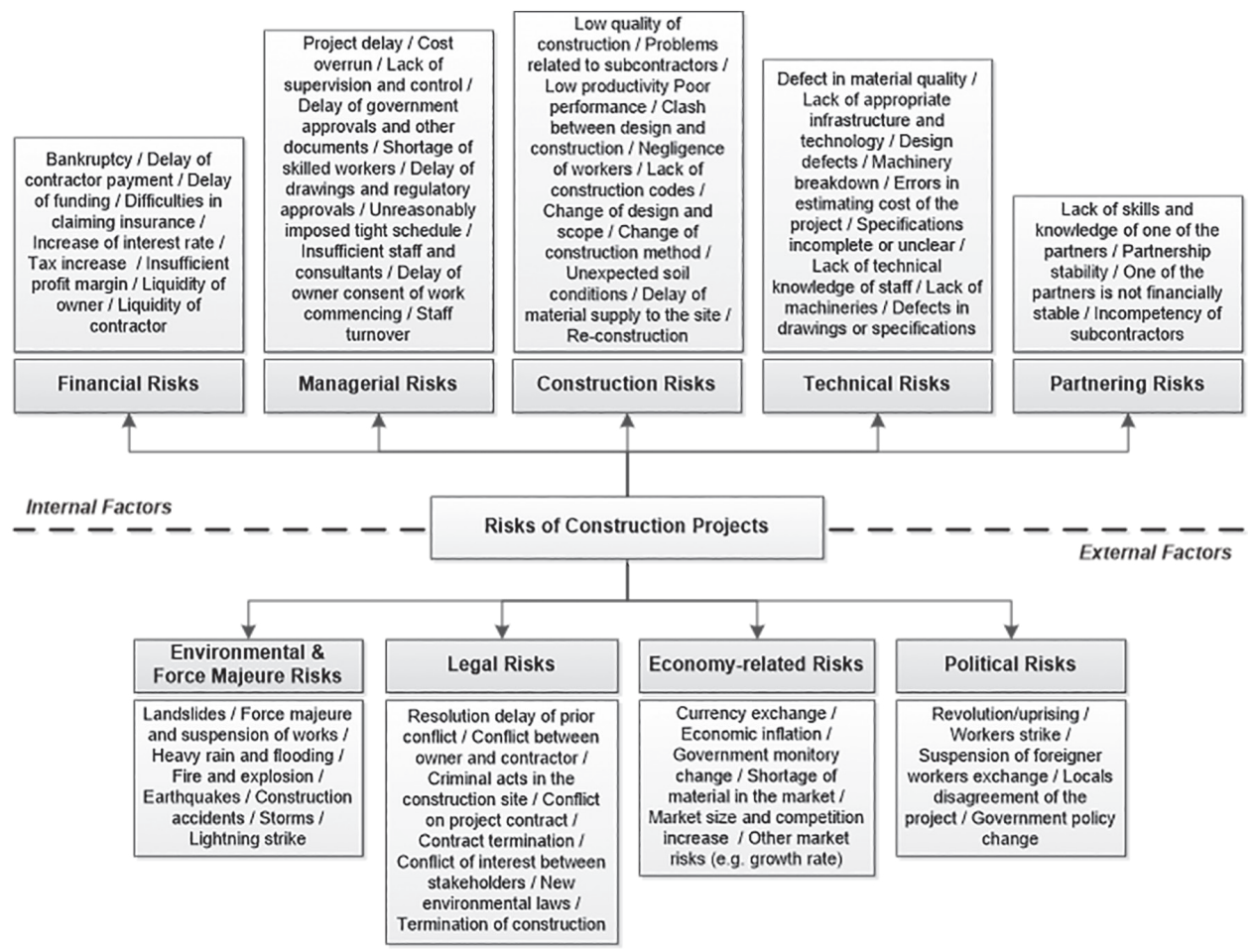

Figure 1. Taxonomy of Risk Variables in Construction Projects

Accordingly, risk variables can be classified into the following categories: (1) economy-related, (2) environmental and force majeure, (3) legal and regulatory, (4) political, (5) managerial, (6) financial, (7) construction-related, (8) technical and (9) partnering risks. The first four categories can be regarded as external or macro-level risks that happen due to conditions that are out of the control of the company or project team. The rest of the categories can be regarded as internal or micro-level risks, which are related to the project per se. 
These categories are presented in Figure 1 and comprise 72 risk variables extracted from previous studies (Abednego and Ogunlana, 2006; Akintoye and MacLeod, 1997; Bing et al., 1999; De Lemos et al., 2004; Edwards and Bowen, 1998; El-Sayegh, 2008; Kindinger and Darby, 2000; Mills, 2001; von Branconi and Loch, 2004; Zayed et al., 2008). The list of identified risks is not exclusive to all risk variables in construction projects. However, the identified risks in Figure 1 represent negative risk variables that may happen in different types of construction projects.

\section{RESEARCH METHODOLOGY}

\section{Survey}

Based on the risk taxonomy proposed in the previous section, a questionnaire survey was developed to determine risk variables in construction projects in Yemen. The questionnaire survey form consisted of two sections. The first section comprised the demographic information and profile of respondents. The second section consisted of 72 statements representing potential risks. In the survey, the risk variable was defined as probability of an event, which, if occurred will cause a negative impact on the project. Respondents have to indicate their opinion about these risks using five-point Likert scale. Number 0 represents "Not a risk", 1 = "Low risk", 2 = "Moderate risk", 3 = "High risk" and 4 = "Very high risk".

\section{Sampling and Data Collection}

Based on the records of the Yemeni Engineers Association, there are slightly more than 5,000 engineers and architects registered in Sana'a branch (https://almehna lst. wordpress.com/). They are working in different ministries, government sectors and private sectors. Due to the unrest situation, it was challenging to approach all of those professionals or other professionals in other cities. It was also difficult to approach engineers situated in construction sites as most of construction projects had been suspended. However, there have been a decent number of engineers and project managers who are attached to the Ministry of Public Works and Roads and its branches and approaching them was possible. Thus, a convenience sampling was selected for this research by targeting respondents based on their availability. This sampling method does not guaranty generalisability of results to the overall population, however it may be the only viable alternative (Sekaran and Bougie, 2016) when special conditions, such as the unrest, make other sampling methods difficult to conduct.

The respondents of the questionnaire survey were mainly engineers and architects who are working in the Ministry of Public Works and Roads or had consultancy works for the ministry. About 300 questionnaire sets were distributed among all professionals in the ministry and its branches. The fieldwork and data collection took about six months.

The total number of questionnaire forms satisfactorily completed was 102 . The respondents were $87 \%$ males and $13 \%$ females with an average age of 32 years old. As shown in Table 1, most of the respondents have a bachelor degree in related field (mostly in civil engineering). The respondents have been working with different construction projects under the government (58\%) or private sector (42\%). 
Table 1. Profile of Respondents

\begin{tabular}{llcc}
\hline Variable & Categories & Percentage (\%) & Cumulative Percent (\%) \\
\hline Education level & High school & 2.0 & 2.0 \\
& Diploma & 7.0 & 9.0 \\
& Bachelor & 82.0 & 91.0 \\
& Master & 8.0 & 99.0 \\
Profession & PhD & 1.0 & 100.0 \\
& Civil engineering & 60.0 & 60.0 \\
& Architecture & 31.0 & 91.0 \\
& Mechanical & 1.0 & 92.0 \\
& Project management & 2.0 & 94.0 \\
& Others & 6.0 & 100.0 \\
Occupation & Project managers & 13.0 & 13.0 \\
& Consultants & 10.0 & 23.0 \\
& Engineers & 36.0 & 59.0 \\
& Designers & 7.0 & 66.0 \\
& Supervisors & 8.0 & 74.0 \\
& Others & 26.0 & 100.0 \\
& Government & 58.0 & 58.0 \\
& Private & 42.0 & 100.0 \\
\hline
\end{tabular}

\section{Procedure of Data Analysis}

The collected data was analysed using two methods, namely factor analysis and the relative importance index (RII). First, the principal component analysis (PCA), which is an approach of factor analysis, was used to reduce number of variables (72 risk variables) to specific number of components or factors (Hair et al., 2006). Empirical evidence from the analysis to identify the number of components depends on one or more of the following criteria (Hair et al., 2006; Tabachnick and Fidell, 2012):

1. Factor loading, which is the correlation between variables and their factors, shall be equal or more than 0.50 .

2. Kaiser-Meyer-Olkin (KMO) shall be conducted to determine the appropriateness of factor analysis. The threshold of $\mathrm{KMO}$ is 0.60 .

3. Bartlett test of sphericity shall be conducted to determine the appropriateness of PCA to the entire correlation matrix (as correlation is expected between risk variables). The result should be significant.

4. Eigenvalue $>1$ shall be used to identify number of components. Alternatively, a fixed number of components can be used but should provide sufficient variance percentage ( 0.60 or higher is the preferred).

5. Factor rotation using Promax method to attain better distribution of the variables. 
The results of KMO and Bartlett's test of Sphericity confirmed that the data is appropriate for factor analysis as shown in Table 2. $\mathrm{KMO}$ is above the threshold 0.6 and Bartlett's result is significant at $p$ value equal 0.000 .

Table 2. KMO and Bartlett's Test

\begin{tabular}{llc}
\hline KMO Measure of Sampling Adequacy & & $\mathbf{0 . 6 4 8}$ \\
\hline Bartlett's Test of Sphericity & Approx. chi-square & 5094.246 \\
& Degree of freedom (df) & 2556 \\
& Significance level (Sig.) & 0.000 \\
\hline
\end{tabular}

Second, the relative importance method provides a simple way to rank variables and refers to "...quantities that compare the contributions of individual explanatory variables to a response variable" (Soofi et al., 2000: 596). In the construction field, Rll has been used to rank different variables such as construction delay factors (Kumaraswamy and Chan, 1998; Sambasivan and Soon, 2007), important skills of effective project leaders (Odusami, 2002), waste management benefits (Tam, 2008), risk factors (El-Sayegh and Mansour, 2015) and cost of quality benefits (Al-Tmeemy et al., 2012). Rll can be calculated using "the average percentage of total explained variance contributed by each variable across all possible subsets" (Baltes et al., 2004: 330) using the following equation (Kumaraswamy and Chan, 1998):

$$
\mathrm{R} \|=\left(\sum w\right) /(A \times N)
$$

where $w$ is weighting given to each factor by the respondents and ranged between 0 and $4, A$ is the highest weight (in this study is 4 ) and $N$ is the sample size (in this study is 102).

The value of RIl ranges from 0 to 1; a higher RIl indicates that a particular variable is more significant than those with relatively lower Rlls. Group or category of variables can also be calculated by averaging the Rlls of all individual factors within the same category (Aibinu and Jagboro, 2002; Chan and Kumaraswamy, 2002). However, there is no threshold of a significant Rll available in the literature. Some authors used threshold of 0.6 or 0.7 of RII (Park, 2009) and others explained the top 5 or top 10 variables (El-Sayegh and Mansour, 2015). We suggest using a threshold that includes the top 25\% of the RII. This represents the third quartile (Q3) of the data and is closely similar to the common 20/80 ratio of Pareto. The threshold can be calculated as the following:

$$
T=[(H R S-L R S) \times 0.75]+L R S
$$

where $T$ is the threshold for significant RIl scores (top $25 \%$ of the data), HRS is the highest RII score and LRS is the lowest RII score. 


\section{RESULTS AND DISCUSSION}

\section{Categories of Risk Variables}

Table 3 shows the results of the rotated matrix of PCA. The analysis refined the 72 variables to 44 variables under eight components. Variables with factor loading less than 0.5, which do not contribute much to the component, have been eliminated from the results. The eight components account for about $53 \%$ of the cumulative variance percentage. Including more than eight components can increase the cumulative percentage but it will result in components with small number of variables (i.e., one or two variables for each component). The name of the new components can be chosen based on all variables represent these components.

Table 3. Results of Principal Component Analysis

\begin{tabular}{|c|c|c|c|c|c|c|c|c|}
\hline \multirow[b]{2}{*}{ Risk Variables } & \multicolumn{8}{|c|}{ Risk Components } \\
\hline & 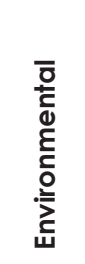 & 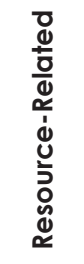 & 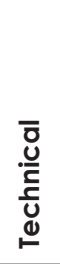 & 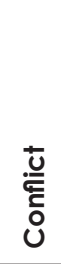 & 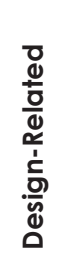 & 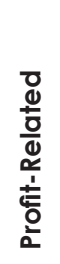 & 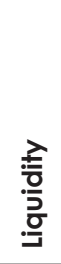 & 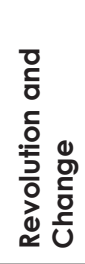 \\
\hline Storms & 0.86 & & & & & & & \\
\hline New environmental laws & 0.83 & & & & & & & \\
\hline Lightning strike & 0.82 & & & & & & & \\
\hline Heavy raining and flooding & 0.70 & & & & & & & \\
\hline $\begin{array}{l}\text { Negative environmental influence } \\
\text { of the project }\end{array}$ & 0.68 & & & & & & & \\
\hline Fire and explosions & 0.62 & & & & & & & \\
\hline Earthquakes & 0.61 & & & & & & & \\
\hline Landslides & 0.58 & & & & & & & \\
\hline Re-construction & 0.54 & & & & & & & \\
\hline $\begin{array}{l}\text { Market size and competition } \\
\text { increase }\end{array}$ & 0.52 & & & & & & & \\
\hline Delay of material delivery & & 0.75 & & & & & & \\
\hline Insufficient staff and workers & & 0.69 & & & & & & \\
\hline Material quality default & & 0.68 & & & & & & \\
\hline Staff turnover & & 0.66 & & & & & & \\
\hline Lack of materials & & 0.65 & & & & & & \\
\hline Unexpected soil conditions & & 0.63 & & & & & & \\
\hline Insufficient skilled workers & & 0.52 & & & & & & \\
\hline Lack of machineries & & 0.51 & & & & & & \\
\hline
\end{tabular}


Table 3. (continued)

\begin{tabular}{|c|c|c|c|c|c|c|c|c|}
\hline \multirow[b]{2}{*}{ Risk Variables } & \multicolumn{8}{|c|}{ Risk Components } \\
\hline & 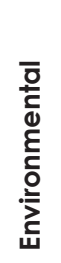 & 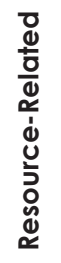 & 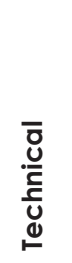 & 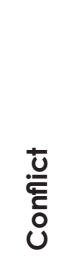 & 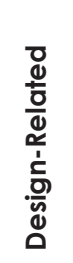 & 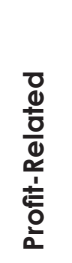 & 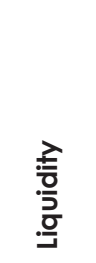 & 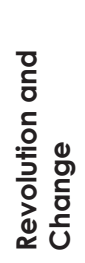 \\
\hline $\begin{array}{l}\text { Lack of appropriate infrastructure } \\
\text { and technology }\end{array}$ & & & 0.83 & & & & & \\
\hline $\begin{array}{l}\text { Specifications incomplete or } \\
\text { unclear }\end{array}$ & & & 0.68 & & & & & \\
\hline $\begin{array}{l}\text { Lack of skills and knowledge of } \\
\text { one of partners }\end{array}$ & & & 0.61 & & & & & \\
\hline Lack of supervision and control & & & 0.58 & & & & & \\
\hline $\begin{array}{l}\text { One of partners is not financially } \\
\text { stable }\end{array}$ & & & 0.56 & & & & & \\
\hline Unskilled subcontractors & & & 0.53 & & & & & \\
\hline Lack of construction codes & & & 0.52 & & & & & \\
\hline Termination of construction & & & & 0.77 & & & & \\
\hline Delay of conflict resolution & & & & 0.61 & & & & \\
\hline Locals disagreement of the project & & & & 0.61 & & & & \\
\hline Criminal acts in construction site & & & & 0.53 & & & & \\
\hline Conflict of project contract & & & & 0.52 & & & & \\
\hline $\begin{array}{l}\text { Defects in drawings or } \\
\text { specifications }\end{array}$ & & & & & 0.78 & & & \\
\hline $\begin{array}{l}\text { Mistakes in estimating of } \\
\text { project cost }\end{array}$ & & & & & 0.74 & & & \\
\hline Change of design and scope & & & & & 0.69 & & & \\
\hline $\begin{array}{l}\text { Delay of drawings or information } \\
\text { about project }\end{array}$ & & & & & 0.58 & & & \\
\hline Difficulties in insurance & & & & & & 0.68 & & \\
\hline Low productivity & & & & & & 0.65 & & \\
\hline Insufficient profit margin & & & & & & 0.62 & & \\
\hline Increase of interest rate & & & & & & 0.52 & & \\
\hline Liquidity of owner & & & & & & & -0.87 & \\
\hline Liquidity of contractor & & & & & & & -0.85 & \\
\hline $\begin{array}{l}\text { Delay of government approvals } \\
\text { and other documents }\end{array}$ & & & & & & & 0.57 & \\
\hline Government policy change & & & & & & & & 0.61 \\
\hline Revolution/uprising & & & & & & & & 0.54 \\
\hline Tax increase & & & & & & & & 0.52 \\
\hline
\end{tabular}


In the first component, 10 risk variables are categorised under the environmental risk, which include natural calamities such as storms, flooding and earthquakes, as well as external variables such as new environmental laws and market competition increase. Mitigating the environmental risks is difficult and stakeholders usually accept these risks. For instance, contractors may be granted extension of time for delay of construction work due to flooding or other force majeure. The second risk factor is resource-related risk, which comprises variables related to materials, machineries and manpower. This factor includes also issues related to resources such as turnover and low skill level of staff. The variable "unexpected soil conditions" seems not related much to this factor. However, this variable might be related to the level of machineries used in the project, which can affect contractor's ability to deal with unexpected soil conditions during construction. The third factor is technical risk, which comprises seven variables relevant to competencies and technical knowledge of project participants. This factor also involves external risks that may affect the project such as lack of infrastructure and technology and construction codes needed. Overcoming these risks is important to support the project during different phases and to ensure good project performance. The fourth factor, called conflict, contains two types of conflict. The first type contains basic variables such as delay of conflict resolution, local community disagreement with the project and conflict on project contract. The second type is related to the causes of conflict including termination of contract and criminal acts in the site. The fifth factor comprises risks related to design and the work of project consultants, mainly the architect. For example, the construction work in site can be affected when there is a defect in the drawing or when the drawings are not submitted to the contractor on time. In addition, the construction can be affected when the cost is estimated incorrectly or there are many changes to the design and project scope.

The sixth factor can be called profit-related risk, which comprises of insufficient profit margin, increase of interest rate, low productivity and difficulty related to insurance. All these variables are related to contractors and reduce their profit. The seventh factor comprises three variables about liquidity of contractor and client and delay of approvals from government, which may affect liquidity. In some government-type projects, progress payment might be delayed and subsequently affect liquidity of the contractor. Liquidity of both contractor and client has negative consequences on the project causing project delay and other issues. The last factor is related to change and revolution. It comprises three interrelated variables including revolution, change in government policy and tax increase. The last variable is related to government policy change.

Based on the average RII of all variables under each components (not shown here), the significant risk components were determined. As shown in Figure 2, the new classification of risk factors in construction projects in Yemen included eight components. Three of these components are deemed significant, which are resource-related risks, technical risks, conflict and revolution and change. These components represent two general types of risks, namely, external and internal. Similar to the findings of El-Sayegh and Mansour (2015), it seems that the internaltype of risk are more common in construction projects in Yemen. This indicates the importance of paying attention to the management of internal risks to achieve good project performance. Although revolution and change have significantly influenced construction projects, these are sudden and irregular incidents and their impact will diminish over time. 


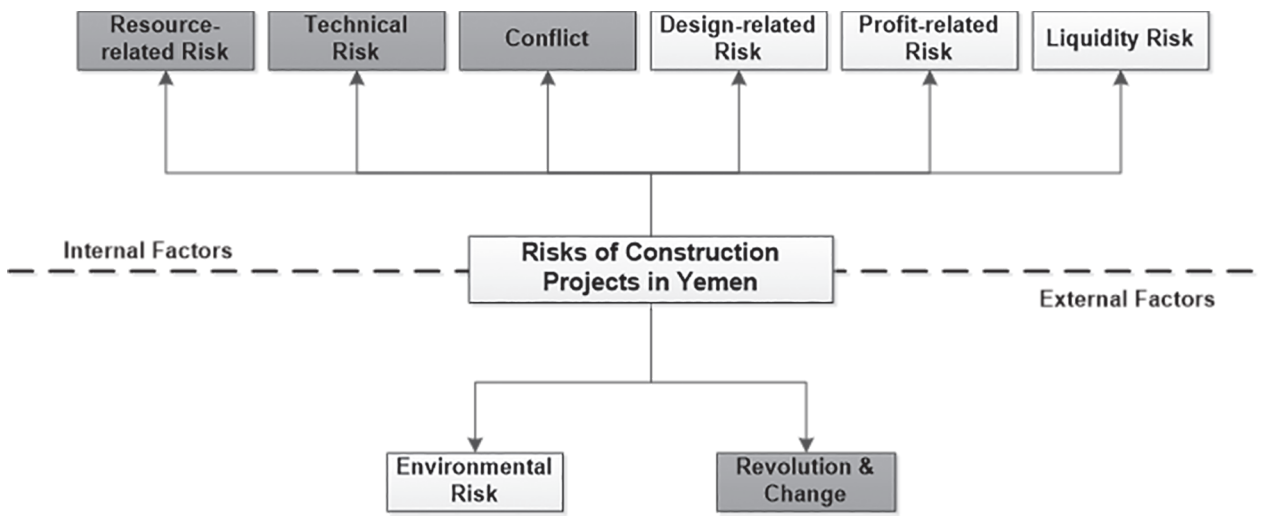

Note: Components highlighted in gray color are more significant.

Figure 2. Risk Components in Construction Projects in Yemen

\section{Significant Risk Variables}

Further analysis of the data was conducted to identify top single variables using Equation 2 as the following:

$$
T=([0.75-0.36] \times 0.75)+0.36=0.292+0.36=0.652
$$

Therefore, Rlls value of 0.65 and above is considered the threshold to determine the top risk variables among the 72 risk variables. Based on this value, the top risk variables included a list of 14 variables as shown in Table 4 . The ranking of all 72 variables based on Rll scores can be found in the Appendix. The result also shows risk allocation between the contractor and client/owner and risk response strategies.

The top risk variable influences construction projects in Yemen is revolution or uprising. While conducting this study, Yemen was witnessing a revolution as part of what is called the "Arab Spring", which started on February 201 1. Later, this revolution was distorted to a major conflict leading to civil war and external war. As whole country affected, the construction industry has influenced by the revolution. The risk of revolution, compared with other risk variables, is a rare and sudden event. This risk is low in terms of probability but has a major influence. The respondents perceived this variable as the top risk because it contributed to delaying or even cancellation of major projects in the country.

The second risk variable is delay of conflict resolution. The delay of resolving conflict may have negative subsequences such as cost overrun, project delay and bad relationship among project stakeholders. Another variable related to conflict is conflict between owner and contractor, which is ranked seventh among other risk variables. This type of conflict occurs due to late payment, scope change and quality issue. The third variable is project delay. Other forms of delay, which contribute to some issues such as conflict, include delay of contractor payment and delay of funding ranked sixth and 13th respectively. 
Table 4. Top Risk Variables in Construction Projects in Yemen

\begin{tabular}{|c|c|c|c|c|}
\hline Risk Variable & Ranking & RII & Risk Response/Management & Risk Allocation \\
\hline Revolution/uprising & 1 & 0.75 & $\begin{array}{l}\text { Engagement of "construction } \\
\text { community" and collaboration } \\
\text { with external organisations } \\
\text { including government and } \\
\text { non-government agencies }\end{array}$ & $\begin{array}{l}\text { Shared (or } \\
\text { not decided)/ } \\
\text { Government }\end{array}$ \\
\hline $\begin{array}{l}\text { Delay of conflict } \\
\text { resolution }\end{array}$ & 2 & 0.72 & $\begin{array}{l}\text { Conflict management system: } \\
\text { good communication, } \\
\text { appropriate resolution method, } \\
\text { role of project managers or } \\
\text { third party, role of common } \\
\text { law and court system }\end{array}$ & Shared \\
\hline Project delay & 3 & 0.70 & $\begin{array}{l}\text { Project management system: } \\
\text { controlling schedule and } \\
\text { changes }\end{array}$ & Contractor \\
\hline $\begin{array}{l}\text { Bankruptcy of } \\
\text { contractor or owner }\end{array}$ & 4 & 0.69 & $\begin{array}{l}\text { Selection of reputable } \\
\text { contractor/development of } \\
\text { financing channels for client }\end{array}$ & $\begin{array}{l}\text { Contractor/ } \\
\text { Client }\end{array}$ \\
\hline $\begin{array}{l}\text { Lack of supervision } \\
\text { and control }\end{array}$ & 5 & 0.68 & $\begin{array}{l}\text { Project management system: } \\
\text { effective monitoring and } \\
\text { control }\end{array}$ & Client \\
\hline $\begin{array}{l}\text { Delay of contractor } \\
\text { payment }\end{array}$ & 6 & 0.68 & $\begin{array}{l}\text { Development of financing } \\
\text { channels }\end{array}$ & $\begin{array}{l}\text { Client (or not } \\
\text { decided) }\end{array}$ \\
\hline $\begin{array}{l}\text { Conflict between } \\
\text { owner and } \\
\text { contractor }\end{array}$ & 7 & 0.68 & $\begin{array}{l}\text { Clear definition of the contract } \\
\text { and resolving disagreements } \\
\text { between parties }\end{array}$ & Shared \\
\hline Low quality building & 8 & 0.68 & $\begin{array}{l}\text { Quality management and } \\
\text { assurance and monitoring and } \\
\text { controlling supplies }\end{array}$ & Contractor \\
\hline Cost overrun & 9 & 0.66 & $\begin{array}{l}\text { Accurate estimation, conflict } \\
\text { resolution, reduction of } \\
\text { disclaimer and price adjustment } \\
\text { clauses in contracts and } \\
\text { controlling changes }\end{array}$ & $\begin{array}{l}\text { Contractor } \\
\text { (or shared) }\end{array}$ \\
\hline $\begin{array}{l}\text { Unskilled } \\
\text { subcontractors }\end{array}$ & 10 & 0.66 & $\begin{array}{l}\text { Employing experienced and } \\
\text { familiar subcontractors }\end{array}$ & Contractor \\
\hline $\begin{array}{l}\text { Lack of appropriate } \\
\text { infrastructure and } \\
\text { technology }\end{array}$ & 11 & 0.66 & $\begin{array}{l}\text { Changing project objectives } \\
\text { and requirements }\end{array}$ & Contractor \\
\hline $\begin{array}{l}\text { Material quality } \\
\text { defect }\end{array}$ & 12 & 0.66 & $\begin{array}{l}\text { Strengthening supervision of } \\
\text { project quality }\end{array}$ & Contractor \\
\hline Delay of funding & 13 & 0.65 & $\begin{array}{l}\text { Development of financing } \\
\text { channels }\end{array}$ & Client \\
\hline $\begin{array}{l}\text { Criminal acts in } \\
\text { construction site }\end{array}$ & 14 & 0.65 & Security and site management & $\begin{array}{l}\text { Contractor (or } \\
\text { not decided) }\end{array}$ \\
\hline
\end{tabular}

Note: Risk response strategies between brackets are proposed by the authors. 
Risk of bankruptcy of contractor ranked fourth, which indicates many issues in selecting contractors who have the financial and technical ability to complete projects. Lack of supervision and control ranked fifth indicating another problem related to construction site, which significantly affect project quality and schedule (this is supported also by the problem of unskilled subcontractors, which is ranked 10th). Other significant variables affect construction projects include cost overrun, lack of appropriate infrastructure and technology, material quality defect and criminal acts in construction such as trespassing and stealing, which ranked ninth, 11 th, 12th and 14th respectively.

\section{Risk Response and Allocation Strategies}

Risk response and risk allocation strategies to the top risk variables in construction projects in Yemen are developed based on the available literature and authors' own experience (refer to Table 4). Previous studies did not indicate clear countermeasures or response strategies to the revolution or uprising risk. Political risks are generally difficult to manage (Trangkanont and Charoenngam, 2014). When dealing with natural disasters such as earthquakes, storms and floods, Tad and Janardhanan (2016) emphasised the importance of participation of community directly affected by the risk. They called for community active engagement in disaster management or what is known as Community Based Disaster Management. We argue that, dealing with wars or revolutions, which are manmade disasters, requires project stakeholders and construction key players (i.e., "construction community") to engage in all aspects of disaster management including prevention, mitigation, preparedness and response. The construction community should engage in the analysis of how construction projects are being affected by the revolution or war. In addition, the construction community should be empowered and provided with necessary facilities and resources to recover losses. Collaboration between the construction community and external organisation (e.g. government and nongovernment agencies) is significant for effective risk response.

The second significant risk, which is delay of conflict resolution, may happen due to lack of collaboration between the client and contractor. A good conflict management system should be put in place. For fast conflict resolution, the following elements should be considered: effective communication between the parties, appropriate resolution method, role of third party such as the project manager or mediator (to effect the appropriate resolution method) and court procedure that allow for fast resolution. Response methods to other significant risk variables are shown as follows:

1. Conflict between owner and contractor: Clear definition of contract terms and resolve disagreements (Hwang et al., 2016).

2. Cost overrun: Controllable risks through accurate estimation, conflict resolution, reduce inclusion of disclaimer and price adjustment clauses in contracts (Perez et al., 2016).

3. Unskilled subcontractors: Use experienced and familiar subcontractors (Hwang et al., 2016).

4. Material quality defect: Strengthening supervision of project quality (Zhang, 2016).

5. Delay of project funding: Developing financing channels (Zhang, 2016). 
Risk allocation of disasters can be a frequent source of dispute between the client and contractor (Smith et al., 2006). Therefore, based on the results of El-Sayegh and Mansour (2015), allocating of force majeure risk is not decided to any party. The allocation of the threat of war can be shared between both client and contractor (El-Sayegh, 2008) or allocated to the client alone (El-Sayegh and Mansour, 2015). In public-private partnership projects, Li et al. (2016) indicated that all political or policy-related risks are allocated to public while force majeure risk is to be shared. In general, political risk requires government involvement to facilitate risk management (Smith et al., 2006). Thus, risk may be allocated to the government or external agencies as another party. The allocation of other risks is highlighted as follows:

1. Delay of conflict resolution: Shared (El-Sayegh, 2008).

2. Project delay: Private sector (i.e., contractor) (Li et al., 2016).

3. Delay of contractor payment: Not decided (El-Sayegh, 2008; El-Sayegh and Mansour, 2015).

4. Conflict between owner and contractor (if due to change in contract): Shared (Li et al., 2016).

5. Low quality building: Contractor (El-Sayegh and Mansour, 2015; Li et al., 2016).

6. Cost overrun: Private sector (i.e., contractor) (Li et al., 2016).

7. Unskilled subcontractors: Contractor (El-Sayegh, 2008).

8. Lack of appropriate infrastructure and technology: Contractor (El-Sayegh and Mansour, 2015).

9. Material quality defect: Contractor (El-Sayegh, 2008).

10. Criminal acts in site: Not decided (El-Sayegh and Mansour, 2015) or shared (El-Sayegh, 2008).

\section{CONCLUSION}

The critical risk factors affecting construction projects in Yemen are mostly internal or related to the project, while two factors are deemed to be external: revolution and change and environmental risks. Further analysis identified top and significant risk variables in construction projects. Revolution, as external risk variable, was ranked top followed by other internal risk variables such as delay of conflict resolution, project delay and bankruptcy. This result indicated that most of the negative risks influencing construction projects in Yemen are project-related or internal. However, a rare risk, such as revolution or war, may occur and have extreme impact on construction projects.

The results of this study contribute to providing better understanding of risk factors and their negative impact on construction projects in Yemen. The strategies of risk response and risk allocation, which identified in this paper, represent a general guideline of risk management during unrest periods as well as during normal situations. Project managers and other professionals can use the proposed classification to develop plan to overcome and manage risks in such situations. By doing so, project managers can ensure that their projects will be prone to less loses and will be completed within the constraints of scope, time, cost and quality. 
Due to difficulty in data collection during the unrest period, a purposive sampling method was used to collect information from professionals working in in the Ministry of Public Works and Roads in the capital city of Yemen. This is a limitation of this study and caution should be warranted when generalising the results to the whole construction sector in Yemen. However, regardless of this limitation, this paper might be the first attempt to study construction risk management in Yemen. Future research can be dedicated to study the effectiveness of risk response strategies proposed in this paper.

\section{ACKNOWLEDGEMENT}

We are grateful to the anonymous respondents of this study whom, regardless of the war and difficult situation, showed enthusiasm and interest to complete the survey. We thank Ayman Abdullah Ayssa for his efforts to collect a good sum of the survey forms.

\section{APPENDIX}

List of risk variables ranked based on highest to lowest Rlls:

\begin{tabular}{lcccc}
\hline Variable & RII & Mean & $\begin{array}{c}\text { Standard Error } \\
\text { of Mean }\end{array}$ & $\begin{array}{c}\text { Standard } \\
\text { Deviation }\end{array}$ \\
\hline Revolution/uprising & 0.75 & 3.02 & 0.10 & 1.03 \\
Delay of conflict resolution & 0.72 & 2.88 & 0.10 & 0.99 \\
Project delay & 0.70 & 2.81 & 0.10 & 1.00 \\
Bankruptcy & 0.69 & 2.77 & 0.12 & 1.18 \\
Lack of supervision and control & 0.68 & 2.73 & 0.10 & 1.00 \\
Delay of contractor payment & 0.68 & 2.73 & 0.10 & 0.98 \\
Conflict between owner and contractor & 0.68 & 2.71 & 0.09 & 0.93 \\
Low quality building & 0.68 & 2.71 & 0.11 & 1.11 \\
Cost overrun & 0.66 & 2.66 & 0.09 & 0.90 \\
Unskilled subcontractors & 0.66 & 2.66 & 0.11 & 1.09 \\
Lack of appropriate infrastructure & 0.66 & 2.64 & 0.10 & 0.97 \\
and technology & & & & \\
Material quality default & 0.66 & 2.63 & 0.11 & 1.08 \\
Delay of funding & 0.65 & 2.61 & 0.10 & 0.99 \\
Criminal acts in construction site & 0.65 & 2.59 & 0.12 & 1.18 \\
Machinery breakdown & 0.64 & 2.57 & 0.10 & 1.01 \\
Locals disagreement of the project & 0.64 & 2.56 & 0.11 & 1.09 \\
Design defects & 0.64 & 2.55 & 0.10 & 1.04 \\
Lack of skills and knowledge of one & 0.63 & 2.54 & 0.10 & 1.00 \\
of partners & & & & \\
\hline
\end{tabular}


Appendix (continued)

\begin{tabular}{|c|c|c|c|c|}
\hline Variable & RII & Mean & $\begin{array}{l}\text { Standard Error } \\
\text { of Mean }\end{array}$ & $\begin{array}{l}\text { Standard } \\
\text { Deviation }\end{array}$ \\
\hline Currency exchange & 0.63 & 2.53 & 0.10 & 1.00 \\
\hline Problems related to subcontractors & 0.63 & 2.53 & 0.10 & 1.02 \\
\hline Termination of construction & 0.63 & 2.51 & 0.10 & 1.06 \\
\hline Clash between design and construction & 0.62 & 2.49 & 0.09 & 0.93 \\
\hline Specifications incomplete or unclear & 0.62 & 2.49 & 0.09 & 0.92 \\
\hline Lack of technical knowledge & 0.62 & 2.48 & 0.09 & 0.94 \\
\hline Landslides & 0.62 & 2.48 & 0.12 & 1.23 \\
\hline Government monitory change & 0.62 & 2.47 & 0.10 & 0.99 \\
\hline Poor performance & 0.62 & 2.47 & 0.10 & 0.99 \\
\hline Government policy change & 0.62 & 2.46 & 0.11 & 1.13 \\
\hline $\begin{array}{l}\text { Delay of government approvals and } \\
\text { other documents }\end{array}$ & 0.62 & 2.46 & 0.11 & 1.08 \\
\hline Mistakes in estimating of project cost & 0.62 & 2.46 & 0.09 & 0.91 \\
\hline Economic inflation & 0.61 & 2.42 & 0.11 & 1.09 \\
\hline Negligence of workers & 0.61 & 2.42 & 0.11 & 1.09 \\
\hline Low productivity & 0.60 & 2.41 & 0.09 & 0.95 \\
\hline Lack of machineries & 0.60 & 2.38 & 0.10 & 1.01 \\
\hline Lack of construction codes & 0.59 & 2.36 & 0.10 & 1.01 \\
\hline Conflict of project contract & 0.59 & 2.35 & 0.10 & 1.00 \\
\hline Defects in drawings or specifications & 0.59 & 2.35 & 0.12 & 1.18 \\
\hline Insufficient skilled workers & 0.58 & 2.33 & 0.11 & 1.10 \\
\hline Difficulties in insurance & 0.58 & 2.33 & 0.09 & 0.93 \\
\hline One of partners is not financially stable & 0.58 & 2.33 & 0.09 & 0.96 \\
\hline Increase of interest rate & 0.58 & 2.30 & 0.11 & 1.09 \\
\hline Delay of drawings/documents & 0.57 & 2.27 & 0.10 & 1.05 \\
\hline $\begin{array}{l}\text { Delay of drawings or information } \\
\text { about project }\end{array}$ & 0.56 & 2.24 & 0.10 & 0.98 \\
\hline Lack of materials & 0.56 & 2.23 & 0.11 & 1.12 \\
\hline Insufficient schedule & 0.56 & 2.23 & 0.10 & 0.97 \\
\hline Tax increase & 0.55 & 2.19 & 0.10 & 1.06 \\
\hline Change of design and scope & 0.54 & 2.15 & 0.10 & 1.06 \\
\hline $\begin{array}{l}\text { Negative environmental influence } \\
\text { of the project }\end{array}$ & 0.54 & 2.15 & 0.12 & 1.21 \\
\hline Contract cancellation & 0.53 & 2.13 & 0.12 & 1.23 \\
\hline Workers strike & 0.53 & 2.13 & 0.11 & 1.09 \\
\hline Change of construction method & 0.53 & 2.12 & 0.10 & 1.03 \\
\hline Partnership stability & 0.53 & 2.11 & 0.10 & 1.04 \\
\hline
\end{tabular}


Appendix (continued)

\begin{tabular}{lcccc}
\hline Variable & RII & Mean & $\begin{array}{c}\text { Standard Error } \\
\text { of Mean }\end{array}$ & $\begin{array}{c}\text { Standard } \\
\text { Deviation }\end{array}$ \\
\hline Fire and explosion & 0.52 & 2.10 & 0.13 & 1.26 \\
Unexpected soil conditions & 0.52 & 2.09 & 0.11 & 1.09 \\
Heavy raining and flooding & 0.52 & 2.09 & 0.12 & 1.17 \\
Insufficient profit margin & 0.52 & 2.08 & 0.10 & 0.97 \\
Delay of material delivery & 0.51 & 2.05 & 0.10 & 1.01 \\
Foreigner exchange suspension & 0.51 & 2.03 & 0.12 & 1.19 \\
Earthquakes & 0.51 & 2.03 & 0.15 & 1.52 \\
Construction accidents & 0.50 & 1.99 & 0.10 & 1.03 \\
Other market risk (e.g. growth rate) & 0.50 & 1.98 & 0.10 & 0.96 \\
Insufficient staff and workers & 0.49 & 1.95 & 0.13 & 1.27 \\
Conflict of interest between stakeholders & 0.49 & 1.95 & 0.09 & 0.94 \\
Liquidity of owner & 0.48 & 1.92 & 0.12 & 1.20 \\
Delay of owner consent of & 0.48 & 1.91 & 0.11 & 1.14 \\
work commencement & & & & \\
Market size and competition increase & 0.48 & 1.90 & 0.10 & 1.06 \\
Re-construction & 0.47 & 1.87 & 0.11 & 1.09 \\
Liquidity of contractor & 0.46 & 1.85 & 0.13 & 1.27 \\
Storms & 0.45 & 1.80 & 0.12 & 1.18 \\
Staff turnover & 0.43 & 1.73 & 0.11 & 1.15 \\
New environmental laws & 0.43 & 1.72 & 0.11 & 1.11 \\
Lightning strike & 0.36 & 1.42 & 0.11 & 1.15 \\
\hline & & & & \\
\hline
\end{tabular}

\section{REFERENCES}

Abednego, M.P. and Ogunlana, S.O. (2006). Good project governance for proper risk allocation in public-private partnerships in Indonesia. International Journal of Project Management, 24(7): 622-634. https://doi.org/10.1016/j. ijproman.2006.07.010.

Ahadzie, D., Proverbs, D. and Olomolaiye, P. (2008). Critical success criteria for mass house building projects in developing countries. International Journal of Project Management, 26(6): 675-687. https://doi.org/10.1016/j.ijproman.2007.09.006.

Aibinu, A. and Jagboro, G. (2002). The effects of construction delays on project delivery in Nigerian construction industry. International Journal of Project Management, 20(8): 593-599. https://doi.org/10.1016/S0263-7863(02)00028-5.

Akintoye, A.S. and MacLeod, M.J. (1997). Risk analysis and management in construction. International Journal of Project Management, 15(1): 31-38. https://doi.org/10.1016/S0263-7863(96)00035-X.

Al-Sabahi, M.H., Al-Hamidi, A.A., Ramly, A. and Rejab, K.M. (2014). Exploring criteria and critical factors for governmental projects implementation in Yemen: A case study. Journal of Surveying, Construction and Property, 5(2): 1-17. https://doi.org/10.22452/jscp.vol5no2.2. 
Al-Tmeemy, S.M.H., Rahman, H.A. and Harun, Z. (2012). Contractors' perception of the use of costs of quality system in Malaysian building construction projects. International Journal of Project Management, 30(7): 827-838. https://doi. org/10.1016/j.ijproman.2011.12.001.

Alaghbari, W., Salim, A., Dola, K. and Ali, A.A.A. (2011). Developing affordable housing design for low income in Sana'a, Yemen. International Journal of Housing Markets and Analysis, 4(1): 84-98. https://doi.org/10.1108/17538271111111857.

Baltes, B.B., Parker, C.P., Young, L.M., Huff, J.W. and Altmann, R. (2004). The practical utility of importance measures in assessing the relative importance of workrelated perceptions and organizational characteristics on work-related outcomes. Organizational Research Methods, 7(3): 326-340. https://doi. org/10.1177/1094428104266014.

Bing, L., Akintoye, A., Edwards, J. and Hardcastle, C. (2005). The allocation of risk in PPP/PFI construction projects in the UK. International Journal of Project Management, 23(1): 25-35. https://doi.org/10.1016/j.ijproman.2004.04.006.

Bing, L., Tiong, R.L.K., Fan, W.W. and Chew, D.A.S. (1999). Risk management in international construction joint ventures. Journal of Construction Engineering and Management, 125(4): 277-284. https://doi.org/10.1061/(ASCE)07339364(1999) 125:4(277).

Boykin, R.F., Freeman, R.A. and Levary, R.R. (1984). Risk assessment in a chemical storage facility. Management Science, 30(4): 512-517. https://doi. org/10.1287/mnsc.30.4.512.

Chan, D. and Kumaraswamy, M. (2002). Compressing construction durations: Lessons learned from Hong Kong building projects. International Journal of Project Management, 20(1): 23-35. https://doi.org/10.1016/S0263-7863(00)00032-6.

Chapman, C. and Cooper, D.F. (1983). Risk analysis: Testing some prejudices. European Journal of Operational Research, 14(3): 238-247. https://doi. org/10.1016/0377-2217(83)90260-6.

Chapman, C. and Ward, S.C. (1994). The efficient allocation of risk in contracts. Omega, 22(6): 537-552. https://doi.org/10.1016/0305-0483(94)90046-9.

de Lemos, T., Eaton, D., Betts, M. and de Almeida, L.T. (2004). Risk management in the Lusoponte concession: A case study of the two bridges in Lisbon, Portugal. International Journal of Project Management, 22(1): 63-73. https://doi.org/10.1016/S0263-7863(03)00013-9.

Edwards, P. and Bowen, P. (1998). Risk and risk management in construction: A review and future directions for research. Engineering Construction and Architectural Management, 5(4): 339-349. https://doi.org/10.1108/eb021087.

El-Sayegh, S.M. (2008). Risk assessment and allocation in the UAE construction industry. International Journal of Project Management, 26(4): 431-438. https://doi.org/10.1016/j.jproman.2007.07.004.

El-Sayegh, S.M. and Mansour, M.H. (2015). Risk assessment and allocation in highway construction projects in the UAE. Journal of Management in Engineering, 31 (6): 04015004 . https://doi.org/10.1061/(ASCE)ME.1943-5479.0000365.

Fang, C., Marle, F., Xie, M. and Zio, E. (2013). An integrated framework for risk response planning under resource constraints in large engineering projects. IEEE Transactions on Engineering Management, 60(3): 627-639. https://doi. org/10.1109/TEM.2013.2242078.

Hair, J.F., Black, W.C., Babin, B.J. anderson, R.E. and Tatham, R.L. (2006). Multivariate Data Analysis. 6th Ed. London: Pearson Education International. 
Hwang, B.-G., Zhao, X. and Yu, G.S. (2016). Risk identification and allocation in underground rail construction joint ventures: Contractors' perspective. Journal of Civil Engineering and Management, 22(6): 758-767. https://doi.org/10.3846 /13923730.2014.914095.

Jannadi, O.A. and Almishari, S. (2003). Risk assessment in construction. Journal of Construction Engineering and Management, 129(5): 492-500. https://doi. org/10.1061/(ASCE)0733-9364(2003) 129:5(492).

Jung, J.H., Kim, D.Y. and Lee, H.K. (2016). The computer-based contingency estimation through analysis cost overrun risk of public construction project. KSCE Journal of Civil Engineering, 20(4): 1119-1130. https://doi.org/10.1007/ s12205-015-0184-8.

Kindinger, J.P. and Darby, J.L. (2000). Risk factor analysis: A new qualitative risk management tool. Paper presented at the Proceedings of the Project Management Institute Annual Seminars and Symposium. Houston, Texas, USA, 7-16 September.

Kumaraswamy, M.M. and Chan, D.W.M. (1998). Contributors to construction delays. Construction Management and Economics, 16(1): 17-29. https://doi. org/10.1080/014461998372556.

Li, Y., Wang, X. and Wang, Y. (2016). Using bargaining game theory for risk allocation of public-private partnership projects: Insights from different alternating offer sequences of participants. Journal of Construction Engineering and Management, 143(3): 04016102. https://doi.org/10.1061/(ASCE)CO.19437862.0001249.

Mills, A. (2001). A systematic approach to risk management for construction. Structural Survey, 19(5): 245-252. https://doi.org/10.1108/02630800110412615.

Odusami, K. (2002). Perceptions of construction professionals concerning important skills of effective project leaders. Journal of Management in Engineering, 18(2): 61-67. https://doi.org/10.1061/(ASCE)0742-597X(2002)18:2(61).

Park, S.H. (2009). Whole life performance assessment: Critical success factors. Journal of Construction Engineering and Management, 135(11): 1146-1161. https://doi.org/10.1061/(ASCE)CO.1943-7862.0000090.

Perez, D., Gray, J. and Skitmore, M. (2016). Perceptions of risk allocation methods and equitable risk distribution: A study of medium to large Southeast Queensland commercial construction projects. International Journal of Construction Management, 17(2): 132-141. https://doi.org/10.1080/15623599.2016.123308 7.

Project Management Institute (PMI) (2013). A Guide to the Project Management Body of Knowledge (PMBOK® Guide). 5th Ed. Pennsylvania: PMI Inc.

Sambasivan, M. and Soon, Y.W. (2007). Causes and effects of delays in Malaysian construction industry. International Journal of Project Management, 25(5): 517-526. https://doi.org/10.1016/j.ijproman.2006.11.007.

Sekaran, U. and Bougie, R.J. (2016). Research Methods for Business: A Skill Building Approach. 7th Ed. Chichester, West Sussex: John Wiley and Sons.

Smith, N.J., Merna, T. and Jobling, P. (2009). Managing Risk: In Construction Projects. New Jersey: John Wiley and Sons.

. (2006). Managing Risk in Construction Projects. 2nd Ed. Oxford: Blackwell Publishing. 
Soofi, E.S., Retzer, J.J. and Yasai-Ardekani, M. (2000). A framework for measuring the importance of variables with applications to management research and decision models. Decision Sciences, 31(3): 595-625. https://doi.org/ 10.1111/j.1540-5915.2000.tb00936.x.

Sultan, B. (2005). The construction industry in Yemen: Towards economic sustainability. PhD diss. Queensland University of Technology.

Sultan, B. and Kajewski, S. (2004). Local problems in the construction industry of Yemen. Proceedings: International Symposium on Globalisation and Construction. Bangkok: School of Civil Engineering, Asian Institute of Technology and The International Council on Innovation and Research in Building and Construction (CIB).

Tabachnick, B.G. and Fidell, L.S. (2012). Using Multivariate Statistics. 6th Ed. Boston: Pearson.

Tad, M.S. and Janardhanan, K. (2016). A whole community approach to disaster management: Preparedness, involvement and empowerment for action. Journal of Chemical and Pharmaceutical Sciences, 9(4): 2006-2008.

Tam, V.W.Y. (2008). On the effectiveness in implementing a waste-managementplan method in construction. Waste Management, 28(6): 1072-1080.

Toor, S. and Ogunlana, S.O. (2010). Beyond the "iron triangle": Stakeholder perception of key performance indicators (KPIs) for large-scale public sector development projects. International Journal of Project Management, 28(3): 228-236. https://doi.org/10.1016/j.ijproman.2009.05.005.

Trangkanont, S. and Charoenngam, C. (2014). Private partner's risk response in PPP low-cost housing projects. Property Management, 32(1): 67-94. https://doi. org/10.1108/PM-02-2013-0008.

von Branconi, C. and Loch, C.H. (2004). Contracting for major projects: Eight business levers for top management. International Journal of Project Management, 22(2): 119-130. https://doi.org/10.1016/S0263-7863(03)00014-0.

Yuan, J., Zeng, A.Y., Skibniewski, M.J. and Li, Q. (2009). Selection of performance objectives and key performance indicators in public-private partnership projects to achieve value for money. Construction Management and Economics, 27(3): 253-270. https://doi.org/10.1080/01446190902748705.

Zayed, T., Amer, M. and Pan, J. (2008). Assessing risk and uncertainty inherent in Chinese highway projects using AHP. International Journal of Project Management, 26(4): 408-419. https://doi.org/10.1016/j.ijproman.2007.05.012.

Zhang, S., Zhang, S., Gao, Y. and Ding, X. (2016). Contractual governance: Effects of risk allocation on contractors' cooperative behavior in construction projects. Journal of Construction Engineering and Management, 142(6): 04016005. https://doi.org/10.1061/(ASCE)CO.1943-7862.0001111.

Zhang, Y. (2016). Selecting risk response strategies considering project risk interdependence. International Journal of Project Management, 34(5): 819830. https://doi.org/10.1016/j.ijproman.2016.03.001.

Zhang, Y. and Fan, Z.-P. (2014). An optimization method for selecting project risk response strategies. International Journal of Project Management, 32(3): 412422. https://doi.org/10.1016/j.ijproman.2013.06.006. 